\title{
13. A case study of role of Pancha tikta ghruta kshira basti in Avascular Necrosis of head of femur.
}

Author : Dr Jagdhane C. D.
Address : 26,Shital, Dr. Annie Besant Road, Worli,Mumbai-30
Mobile No :09819968385 ; Email : cjagdhane@ gmail.com
Co-Author : Dr. Yadav Prachi V.
Adress : 204 E Chintamani Nagar, Shiva vallabh Rd. ,Dahisar (East),Mumbai 400068
Mobile No : 09833916622.; Email : yadavprachi3@gmail.com.

\section{Abstract}

Aim:

To evaluate the role of panchatikta ghrita kshira basti in Avascular Necrosis of head of femur

\section{Objectives:}

1. To evaluate the role and mechanism of action of Pancha tikta ghrita kshira basti in AVN.

\section{Observation:}

Follow up was taken after every week in Karma basti karma given to the patient for seven days.Observations were noted in the form of improvement in clinical parameters.

\section{Conclusion:}

Conclusion was drawn from above data.

\section{Introduction:}

Avascular necrosis is a rare entity.In which there is cellular death (necrosis) of bone components due to interruption of the blood supply. Without blood, the bone tissue dies and the bone collapses.If avascular necrosis involves the bones of a joint, it often leads to destruction of the joint articular surfaces.

The sites involved are femoral head, scaphoid bone, lunate bone, talus, lower $1 / 3^{\text {rd }}$ of tibia, rarely head of humerus. Out of these AVN of head of femur is commonly seen.

Exact etiology of this not known but the predisposing factors are, chemotherapy, alcoholism, excessive steroid use, post traumatic. Other rare causes are sickle cell anaemia, hypertension, vasculitis, arterial embolism and thrombosis, damage from radiation, bisphosphonates.

In this case study cause was found to be trauma after RTA and H/O fracture of neck of femur.

Treatment of this AVN depends upon the bone involved in it. But mostly its surgical medicinal treatment is hardly effective in improving patient's condition. In case of upper limb usually limb shortening is done, and in case of lower limb reconstructive procedures are preferred.

In case of AVN of head of femur THR i.e. Total hip replacement is done but, THRs have a number of downsides including long recovery times and short life spans. Instead hip resurfacing or metal on metal (MOM) resurfacing is used now days. But these surgical procedures are costly affairs and in our country everyone can not afford it. Besides it does not replace the function of the joint to its original state, patients movements are restricted.

Thus in this case study alternative method for treating AVN was tried.It is not only very effective but also supported by the fundamentals and basic principals in Ayurveda. Thus it can prove as a ray of hope to the patients suffering from this and those not willing for surgery.

\section{Materials and Methods Material Used:}

Panchatikta bharad, Go-dugdha, Panchatikta Ghrita, Madhu, Glucerine syringe, Simple rubber catheter.(Ref Cha. Su. 28/ 27, ) 


\section{Ayurlog: National Journal of Research in Ayurved Science}

A Web based quarterly online published peer reviewed National E-journal of Ayurveda.

\section{Preparation Method :}

Kshira-paka of panchatikta bharad was made by proportion Bharad : Go-dugdha : Water

as $1: 16: 16$.And it was boled till only milk remains.Then vastra galita kshira-paka was obtained.(Ref : Dravyaguna sangraha by Yadavji trikamji Acharya).

Then from this Pancha-tikta Ghrita-kshira basti was prepared from this by mixing the above contents in following sequence and quantity:

1. Madhu $10 \mathrm{ml}$

2. Panchtikta Ghrita $20 \mathrm{ml}$

This was mixed thoroughly till ghrita particals are mixed completely with madhu.

3. Panchatikta Kshirapaka $100 \mathrm{ml}$. (Ref Ah. Hru.Su. 19/45)

Then this basti was given to the patient by giving him left lateral position by using glycerine syringe and catheter.

Matra of basti was increased by $50 \mathrm{ml}$ every $3^{\text {rd }}$ day till it was $250 \mathrm{ml}$ then this matra was continued for the remaining days. As this was retained for 8 to $12 \mathrm{hrs}$ and patient did not have any complaints.

\section{Case Study}

A male patient came to SOPD of age 37 year.OPD reg. no was 6378. With following complaints

$\mathrm{C} / \mathrm{O}$ : Pain in both lower limbs \& grion ....since 1 year

Both lower limb

weakness............since 1 year

Difficulty in walking................ since 1 year

Pain in lower abdomen...............since 1 year

$\mathrm{H} / \mathrm{O}: \mathrm{h} / \mathrm{o}$ fall from two-wheeler 5-6 months back.There was no evidence of fracture.

$\mathrm{P} / \mathrm{M} / \mathrm{H}$ : $\mathrm{H} / \mathrm{O}$ malaria and enteric fever 8 months back.

No h/o DM/ HTN/ BA/ Kochs.

No h/o any drug allergy.

$\mathrm{P} / \mathrm{S} / \mathrm{H}$ : No evidence of any major surgery.

Ashtavidha Parikshana :
Nadi

78/ $\quad \min$

Shabda - spashta

Mala

malavshthamba

Sparsha - anushna-sheeta

Mutra

prakrut

Druka - prakruta

Jivha

alpa-sama

Aakruti - madhyam

O/E : Pulse : $78 /$ min

B.P: $130 / 70 \mathrm{mmhg}$

G.C. fair

$\mathrm{P} / \mathrm{A}$ : tenderness in hypogastric region.

Strotas Parikshana :

Rasavaha Strotasa : Aruchi, daurbalya.

Asthivaha Strotasa : Asthi shoola(ubhaya vamkshana sandhi shoola)

L/E:

Numbness in both lower legs +++

SLRT: Rt : $65^{\circ} \quad$ Lt : $70^{\circ}$

Movements of B/ L hip joint: flexion, extension, rotation - painful during walking and sitting.

Investigations:

MRI of B/L hip joint (done 8 months before starting treatment) showed

Features suggestive of Avascular Necrosis of B/L femoral heads. (Modified ficat's grade 3 in Right side and Grade 2 on Left side).

\section{Treatment given:}

\section{Aushadhi Chikitsa :}

1) Hingvashtak Churna 3gm B.D. before food with warm water. (Initial 5 days for pachan)

2) Lakshadi Guggul 3 tablets BD after meals i.e. Vyanodan kal.

3) Asthimajjapachak Kwatha BD after food i.e. Vyanodan kal.

\section{Panchakarma Chikitsa :}

1. Sarvanga snehan swedan.

2. Panchatikta-Ghruta-Kshira Basti

(starting from $100 \mathrm{ml}$ to $250 \mathrm{ml}$ ) for 30 days i.e. karma basti krama.

\section{Pathya-Apathya :}

Patient was told to avoid his addiction of chewing tobacco, Viruddha ahara, also 
vataprakopak ruksha ahar.He was adviced to

take intake of Godugdha everyday.

\section{Results;}

Rt Lower Limb :

\begin{tabular}{|c|c|c|c|c|c|c|c|}
\hline \multirow{3}{*}{$\begin{array}{l}\text { Follow } \\
\text { up date }\end{array}$} & \multirow[t]{3}{*}{ SLRT } & \multicolumn{6}{|c|}{ Movements (Pain gradations) } \\
\hline & & \multirow[t]{2}{*}{ Flexion } & \multirow[t]{2}{*}{ Extension } & \multicolumn{2}{|c|}{ Rotation } & \multirow[t]{2}{*}{ Abduction } & \multirow[t]{2}{*}{ Adduction } \\
\hline & & & & External & Internal & & \\
\hline 2-11-11 & $55^{\circ}$ & +++ & +++ & +++ & +++ & +++ & +++ \\
\hline $9-11-11$ & $60^{\circ}$ & +++ & +++ & +++ & +++ & +++ & +++ \\
\hline $15-11-11$ & $60^{\circ}$ & +++ & +++ & +++ & +++ & +++ & +++ \\
\hline $22-11-11$ & $70^{\circ}$ & +++ & ++++ & ++++ & ++++ & ++++ & ++++ \\
\hline 29-11-11 & $80^{\circ}$ & ++++ & ++++ & ++++ & ++++ & ++++ & ++++ \\
\hline $2-1-12$ & $80^{\circ}$ & ++++ & ++++ & ++++ & ++++ & ++++ & ++++ \\
\hline
\end{tabular}

Lt Lower Limb :

\begin{tabular}{|c|c|c|c|c|c|c|c|}
\hline \multirow{3}{*}{$\begin{array}{l}\text { Follow } \\
\text { up date }\end{array}$} & \multirow[t]{3}{*}{ SLRT } & \multicolumn{6}{|c|}{ Movements (Pain gradations) } \\
\hline & & \multirow[t]{2}{*}{ Flexion } & \multirow{2}{*}{$\begin{array}{l}\text { Extensi } \\
\text { on }\end{array}$} & \multicolumn{2}{|c|}{ Rotation } & \multirow[t]{2}{*}{ Abduction } & \multirow[t]{2}{*}{ Adduction } \\
\hline & & & & External & Internal & & \\
\hline $2-11-11$ & $70^{\circ}$ & ++++ & +++ & +++ & +++ & +++ & +++ \\
\hline $9-11-11$ & $70^{\circ}$ & ++++ & +++ & +++ & +++ & +++ & +++ \\
\hline $15-11-11$ & $80^{\circ}$ & ++++ & +++ & +++ & +++ & +++ & +++ \\
\hline $22-11-11$ & $80^{\circ}$ & ++++ & ++++ & ++++ & ++++ & ++++ & ++++ \\
\hline 29-11-11 & $80^{\circ}$ & +++++ & ++++ & ++++ & ++++ & ++++ & ++++ \\
\hline $2-1-12$ & 85 & +++++ & ++++ & ++++ & ++++ & ++++ & ++++ \\
\hline
\end{tabular}

Along with this his limping while walking was completely relieved and he was able to walk without limping at least for 30 to 45 mins.According to the patient his complains were relived satisfactorily and he had $70-80 \%$ relief.

\section{Grade Evaluation for Joint movements:}

Grade 1 : No movement possible.

Grade 2 : Movement by appropriate postural adjustment.

Grade 3 : Movement against gravity but not against external resistance.

Grade 4 : Movement against gravity and against some resistance.

\section{Grade 5 : Normal Movement .}

\section{Discussion:}

Here in this patient trauma after bike accident was the hetu for asthivaha strotas dushti.As told by Acharya charaka 'Asthnam cha ati-

vighattanat',this lead to Asthi-vaha strotas dushti.(Ref : Cha. Viman 5/17)

Thus Chikitsa for asthivaha strotas dushti was given i.e.Panchatikta Ghrita-Kshira Basti(Ref : Cha $\mathrm{Su} 28 / 27$ ), thus lakshadi guggul was also given for asthi vruddhi at the necrosed bone site of femoral head.Asthi majjapachak yog(Ref :Cha Chi 3/202) was given for pachan and it also acts as vehicle and helps other contents of aoushadhi chikitsa to reach upto asthi dhatu.

Besides this according to Acharya Dalhana 'Asthi-dhara kala' is also called as 'Purishdhara kala'which is situated in 'Pakwashaya'.Thus basti given in Pakwashaya directly acts on Asthi-dhara-kala,ultimately leading to poshana of asthi dhatu.(Su sha. 4/16)

\section{Conclusion:}




\section{Ayurlog: National Journal of Research in Ayurved Science}

A Web based quarterly online published peer reviewed National E-journal of Ayurveda.

Thus this was a genuine attempt to treat the patient of AVN with help of Ayurveda, which was successful in improving general condition of the patient without going for the surgey.He was able to carry his daily activities without botheration of his pain. This can be ray of hope on this path. This needs can be a research topic having positive angle, so more work can be done in this direction.

\section{References:}

1. Cha. Su. 28/27 Charak Samhita by Brhamanand Tripathi, Chaukhamba Prakashan.Pg no 550

2. Dravyagunavidnyan by Yadavji trikamji Acharya Kshirapak Kalpana.

3. Ah.Hru.Su. 19/45 Ashtagna Hruday

4. Cha.Chi 3/202 Charak Samhita by Brhamanand Tripathi, Chaukhamba Prakashan.

5. Cha. Vi. 5/17 Charak Samhita by Brhamanand Tripathi, Chaukhamba Prakashan Pg no 699.

6. Su. Sha. 4/16 Sushrut Samhita by Yadavji Trikamji Acharya Chaukhamba Prakashan Pg no 356. 